Türk Turizm Araştırmaları Dergisi
2021, 5(3):1652-1669.
DOI: $10.26677 / T R 1010.2021 .812$
ISSN: 2587-0890 Dergi web sayfasi: https://www.tutad.org

\title{
Konaklama İşletmelerinde Covid-19 Sonrası Uygulanan Sağlık ve Güvenlik Uygulamalarının Örgüte Uyum ve İşgören Performansı Üzerine Etkisi
}

\author{
Öğr. Gör. Gamze ÖZEL, Kilis 7 Aralık Üniversitesi, Turizm ve Otelcilik Meslek Yüksekokulu, \\ Kilis, e-posta: gozel@kilis.edu.tr \\ ORCID: https://orcid.org/0000-0002-9316-7277
}

Öğr. Gör. Aydın İNAK, Gaziosmanpaşa Üniversitesi, Reşadiye Meslek Yüksekokulu, Tokat, eposta: aydin.inak@gop.edu.tr ORCID: https://orcid.org/0000-0003-2993-3659

Cansu ÖZEL, Yüksek Lisans Öğrencisi, Çukurova Üniversitesi, Fen Bilimleri Enstitüsü, Adana, e-posta: cansu.ozell16@gmail.com

ORCID: https://orcid.org/0000-0002-3324-4664

\section{Öz}

Koronavirüs (Covid-19) salgını sonrası insan ilişkilerinin yoğun olduğu turizm sektöründe çalışan ve misafir sağlığını korumaya yönelik pek çok kural uygulanmaya başlanmıştır. Bu kuralların çalışanların örgüte uyum düzeylerine ve performanslarına olası etkilerinin belirlenmesi sektör açısından önem arz etmektedir. Bu kapsamda çalışmada, konaklama işletmelerinde işgörenlerin örgüte uyum düzeyi ve işgören performansının yordayıcısı olarak, covid-19 sonrası uygulanan sağlık ve güvenlik uygulamalarının belirlenmesi amaçlanmıştır. Araştırmanın evreni konaklama tesislerinde çalışanlar olarak belirlenmiştir. Bu kapsamda anket formları oluşturularak Google anket uygulamasıyla ulaşılan 432 personelden geri dönüş alınabilmiştir. Çalışma sonucunda elde edilen bulgulara göre, çalışanların örgüte uyum düzeyinin 3,69 , iş gören performans düzeyinin 3,97, covid-19 sonrası sağlık ve güvenlik uygulamaları düzeyinin ise 3,69 olduğu belirlenmiştir. Elde edilen sonuçlara göre sağlık ve güvenlik uygulamaları ile örgüte uyum ve işgören performansı arasında pozitif yönlü anlamlı ilişki tespit edilmiştir. Sağlık ve güvenlik uygulamalarının alt boyutlarından yönetsel önlem tedbirlerin işgören performansı ve örgüte uyumu negatif yönde, kriterlere göre çalışma, işbirliği ve iletişimin ise pozitif yönde etkilediği belirlenmiştir. Farkındalık ve bilinç alt boyutunun örgüte uyumu negatif yönde etkilediği buna karşın işgören performansı üzerinde anlamlı bir etkisinin olmadığı, eğitim uygulamalarının işgören performansını pozitif yönde, örgüte uyumu ise negatif yönde etkilediği tespit edilmiştir. Ayrıca, covid-19 sonrası sağlık ve güvenlik uygulamalarının örgüte uyumu ve işgören performansını pozitif yönde anlamlı etkilediği sonucuna ulaşılmıştır.

Anahtar Kelimeler: Örgüte Uyum, İşgören Performansı, Sağlık ve Güvenlik, Turizm, Covid-19.

Makale Gönderme Tarihi: 24.03.2021

Makale Kabul Tarihi: 02.09.2021

\footnotetext{
Önerilen Atıf:

Özel, G., İnak, A. ve Özel C. (2021). Konaklama İşletmelerinde Covid-19 Sonrası Uygulanan Sağlık ve Güvenlik Uygulamalarının Örgüte Uyum ve İşgören Performansı Üzerine Etkisi, Türk Turizm Araştırmaları Dergisi, 5(3): 16521669.

(C) 2021 Türk Turizm Araştırmaları Dergisi.
} 


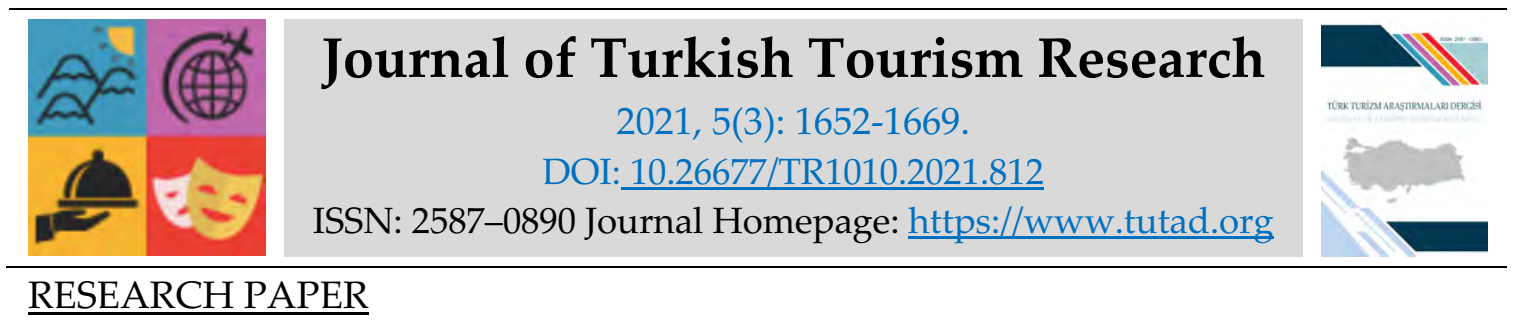

\title{
The Effect of Health and Safety Practices Applied After Covid-19 in Hospitality Businesses on Organizational Cohesion and Employee Performance
}

Lecturer Gamze ÖZEL, Kilis 7 Aralık University, School of Tourism and Hotel Management, Kilis, e-mail: gozel@kilis.edu.tr

ORCID: https://orcid.org/0000-0002-9316-7277

Lecturer Aydın İNAK, Gaziosmanpaşa University, Reşadiye Vocational School, Tokat, e-mail: aydin.inak@gop.edu.tr

ORCID: https://orcid.org/0000-0003-2993-3659

Cansu ÖZEL, MSc. Student, Çukurova University, Institute of Science, Adana, e-mail: cansu.ozell16@gmail.com

ORCID: https://orcid.org/0000-0002-3324-4664

\begin{abstract}
After the coronavirus (Covid-19) epidemic, many rules have been implemented to protect the health of employees and guests in the tourism sector, where human relations are intense. It is important for the sector to determine the possible effects of these rules on the level of adaptation of the employees to the organization and their performance. In this context, In the study, it was aimed to determine the health and safety practices applied after covid-19 as a predictor of the level of compliance of employees in accommodation facilities to the organization and employee performance. The population of the research were determined as employees in accommodation facilities. In this context, feedback was obtained from 432 personnel, who were reached through the Google survey application by creating questionnaires. According to the findings obtained as a result of the study, it was determined that the level of compliance of the employees to the organization was 3.69, the level of performance at the employee was 3.97, and the level of health and safety practices after covid-19 was 3.69. According to the results, a positive and significant relationship was found between health and safety practices, organizational compliance and employee performance. It has been determined that managerial precaution measures, which are sub-dimensions of health and safety practices, have a negative effect on employee performance and organizational compliance, while working, cooperation and communication according to the criteria have a positive effect. It was determined that awareness and consciousness sub-dimension negatively affected organizational compliance, however, it did not have a significant effect on employee performance, training practices positively affect employee performance, and organization compliance negatively. In addition, it was concluded that health and safety practices after covid-19 significantly positively affected organizational compliance and employee performance.
\end{abstract}

Keywords: Harmony the Organization, Employee Performance, Health and Safety, Tourism, Covid-19.

Received: 24.03 .2021

Accepted: 02.09 .2021

Suggested Citation:

Özel, G., İnak, A. and Özel C. (2021). The Effect of Health and Safety Practices Applied After Covid-19 in Hospitality Businesses on Organizational Cohesion and Employee Performance, Journal of Turkish Tourism Research, 5(3): 1652-1669. (C) 2021 Türk Turizm Araştırmaları Dergisi. 


\section{GİRIŞ}

Teknolojinin öneminin artmasıyla birlikte insan faktörünün de önemi anlaşılarak örgütün başarıya ulaşmasında en değerli sermaye olarak görülmüş, böylelikle modern iş yaşamında teknolojik yatırımlar arttırılmakla beraber çalışanlara verilen önem de artmıştır (Özkan, Omay ve Akyüz, 2019:114). Turizm sektörüne bakıldığında ise sektörde oluşan büyümeyle birlikte faaliyet gösteren işletme sayısıyla beraber istihdamın arttığı (İlhan, Gözükara ve Aksu, 2017:2) ve sektörde sunulan hizmetlerin kalitesi, misafir memnuniyeti, işletme verimliliği gibi pek çok husus göz önüne alındığında işletmelerin başarı elde etmelerinde çalışanların payının oldukça büyük olduğu söylenebilir.

Örgütün belirlenen amaçlarına ulaşabilmesinde yetki ve sorumlulukları belirlenmiş olan çalışanın görevlerini yerine getirme düzeylerinin belirlenmesi önem arz etmektedir (Ünsalan ve Şimşeker, 2013:124). Bu kapsamda işgörenlerin performansları, örgütlerin etkin ve verimli olma potansiyelinde belirleyici olmaktadır (Özkan, Omay ve Akyüz, 2019:114). Aynı zamanda örgütle özdeşleşmesi ve değişikliklere uyum sağlamasını ifade eden örgüte uyum (Çalık, 2003) düzeyi düşük olan çalışanlar koşullara uyum sağlayamayarak örgütün başarısızlığına neden olabilecektir. Bu nedenle çalışanların performanslarını veya örgüte uyum sağlamalarını olumlu ya da olumsuz yönde etkileyebilecek durumların tespiti, performanslarını ve uyum sağlamalarını arttırmaya yönelik çeşitli uygulamaların yapılması çalışanlar ve işletme başarısı yönünden önem arz etmektedir. $\mathrm{Bu}$ kapsamda işgörenlerin kendilerini güvende hissedebilecekleri ortamda çalışmaları verimliliklerini etkileyebilmektedir. İşletmelerde uygulanan iş sağlı̆̆ı ve güvenliği uygulamaları sayesinde bireyler güvenli bir çalışma ortamında faaliyet sürdürmekte, mevcut risk ve tehlikelerin mümkün olduğunca azaltılmasıyla birlikte çalışanların güvenliğine yönelik uygun çalışma ortamı sağlanmaktadır. Ancak hastalık veya ölümle sonuçlanan ve pek çok kişiyi etkileyebilecek covid-19 salgınıyla birlikte hem çalışanlar hem de misafirleri etkileyebilecek olan riskler ortaya çıkmış durumdadır.

Dünya Sağlık Örgütü tarafından covid-19 salgını 30 Ocak'ta "uluslararası boyutta halk sağlığı acil durumu" olarak sınıflandırılmış, virüsün yayılımı ve şiddeti ile birlikte ilk salgının başladığı Çin dışında 113 ülkede daha covid-19 vakalarının görülmesi nedeniyle 11 Mart'ta küresel salgın (pandemi) olarak tanımlanmıştır. Türkiye'de ilk vaka Mart ayında görülmüş ve halk sağlığı önlemleri ile vaka hızının düşürülmesi, salgının eğrideki yükselişinin yavaşlatılması, sağlık hizmetine olacak talebin azaltılması için Sağlık Bakanlığı tarafından temel strateji olarak belirlenmiştir (Sağlık Bakanlığı, 2020:5).

Covid-19 salgınıla birlikte Türkiye'de işletmelere yönelik pek çok sağlık tedbirini içeren genelgeler ve çalışma prensipleri oluşturulmuştur. Turizm sektöründe faaliyet gösteren konaklama tesisleri için de ayrıca genelge çıkarılmış ve hem misafirlerin hem de çalışanların sağlığını korumaya yönelik ilkeler belirlenmiştir. Bu kurallara uygun olarak faaliyete başlayan işletmeler sertifikasyon ile güvenli olduklarını belirtmişlerdir. Bu kapsamda işletmenin uygunluğu kadar çalışanlara da hem mevcut uygulamaların devam ettirilmesi hem de sağlıklı ortamın sürdürülebilirliğinin sağlanması için gereken eğitimlerin alınması ve uygulanmasıyla pek çok görev düşmüştür. Konaklama tesislerinde mevcut risklerin yanı sıra ortaya çıan salgın hastalığa yakalanma ve kurallar çerçevesinde uygulanması gerekenlere bakıldığında çalışanlarda stres faktörünü etkilediği söylenebilir.

Tüm dünyada covid-19 ile mücadele edilmesine rağmen salgın yüzbinlerce insanın hayatını kaybetmesine neden olmuş bununla beraber yüzyılın ekonomik açıdan en büyük krizine yol açarak, insanların işlerini kaybetmesine, mutsuz olmalarına ve gelecek kaygısı içinde olmalarına neden olmuştur (Alaediinoğlu ve Rol, 2020:251). Aynı zamanda yapılan çalışmalarda; covid- 19 salgınının kaygıya yol açtığı̆, oluşan kaygının motivasyon ve 
performansı olumsuz olarak etkilediği (Sönmez, 2020:717), covid-19 korkusunun ve iş performansının, işten ayrılma niyetini yordayan önemli değişkenler olduğu belirlenmiştir (Büyükmumcu ve Yiğitol, 2021:3434). Bu kapsamda turizm sektöründe belirlenen uygulamalara çalışanların uyum sağlayabilmesi ve performanslarının sunulan hizmet kalitesini doğrudan etkileyeceği düşünüldüğünde sektörün önemli bir parçası olan insan unsurunun belirlenen kurallarla beraber oluşabilecek değişikliklere uyum sağlayabilmesi aynı zamanda artan iş yükü veya psikolojik etkinin çalışanların performanslarına olası etkilerinin belirlenmesi önem arz etmektedir. Bu nedenle çalışmada, sağlık ve güvenlik uygulamalarının yanı sıra çalışan performansı ve örgüte uyumu üzerinde etkisinin belirlenmesine yönelik bilgiler elde edilmeye çalışılmıştır.

\section{KAVRAMSAL ÇERÇEVE VE LİTERATÜR}

\section{Örgüte Uyum}

Uyum, TDK'ya göre; "bir bütünün parçaları arasında bulunan ya da bulunması gereken uygunluk" olarak tanımlanmaktadır (https://sozluk.gov.tr/). Örgütsel uyum bireyin bulunduğu örgütle özdeşleşebilmesi, ortak amaç ve değerleri paylaşabilmesine dönük çaba harcamak istemesi (Çalık, 2003) olup çalışanların yaşanan olası durumlar karşısında davranışsal açıdan farklı senaryolara sahip olabilme yeteneğidir (Bhattacharya, Gibson ve Doty, 2005:624).

Pulakos, Arad, Donovan ve Plamondon (2000:616) örgüte uyum sağlayıcı performans göstergelerini sekiz boyut olarak ele almıştır. Bunlar; acil durumları veya kriz durumlarını ele almak, çalışma görevlerini, sorunları yaratıcı bir şekilde çözmek, iş stresini ele almak, teknolojilerini ve prosedürlerini öğrenmek, belirsiz ve öngörülemeyen çalışma durumlarıyla uğraşmak, kişilerarası uyarlanabilirliği göstermek, kültürel uyarlanabilirlik ve fiziksel olarak uyarlanabilirlik gösterme olarak boyutlandırmıştır.

Çalışanların performans ve verimliliklerinin örgüte kar olarak yansıması için örgütlerin kendi içindeki uyumlarıyla birlikte, uyumlu çalışanlarla hareket etmesi de etkilidir. Çalışanlar ile örgütlerin ortak paydada buluşabilmeleri ve ortak amaçlar doğrultusunda bütünleşebilmeleri açısından uyumluluk önemlidir (Özkan vd., 2019:114). Değişen bir görev bağlamında iyi performans gösterenlerin yüksek uyarlanabilirliğe sahip olduğu, iyi performans göstermeyenlerin ise düşük uyarlanabilirliğe sahip olduğu söylenebilir (LePine, Colquitt ve Erez, 2000:565). Örgütler çevrelerinde değişimlerden etkilenmekte olup bu değişimler sosyal, ekonomik, siyasi, teknolojik vb. birçok alanda oluşabilmektedir. Örgütlerin başarılı olabilmeleri ancak yaşanan değişimlere uyum sağlayabilmeleri ile mümkün olmaktadır (Güçlü ve Şehitoğlu, 2006:240). Örgütlerin bu değişimlere uyum sağlaması açısından turizm sektöründe çalışanların önemli bir paya sahip oldukları söylenebilir. Çevrede oluşan değişikliklere kolay uyum sağlayabilen işletmelerin başarısında çalışanların değişikliklere uyum sağlama düzeyleri etkili olmaktadır. Bu kapsamda özellikle hizmet sektöründe işi gerçekleştiren işgörenlerin değişime direnç göstermemeleri ve kolay adapte olmaları önem arz etmektedir.

\section{İşgören Performansı}

Performans kavramı, belirli bir sürede bireylerin ya da grupların işlerini gerçekleştirirken göstermiş oldukları eylem veya çabaların sonuçlarıdır. Performans kavramına aslında birey ya da gruptan belirli bir zamanda belirli oranda işin beklenilmesi ve elde edilen çıtıyla karşılaştııılarak değerlendirilmenin yapılmasıyla ulaşılmaktadır (Uysal, 2015:33). İşgören performansının düşük olduğu örgütlerde başarıya ulaşmak güçtür. Bu nedenle örgüte ait 
çalışanların psikolojilerinin araştırılarak performanslarının artırılması için örgüt içi yönetim stratejilerinin uygulanması gerekmektedir (Uysal ve Yıldız, 2013:836). İşletmelerin müşterilerine kaliteli hizmet sunmaları çalışanların performanslarıyla ilgilidir (İplik, 2004:195).

Turizm sektöründe faaliyet gösteren işletmelerin amaçlarına ulaşmaları, verimli olmaları, rekabet üstünlüğü elde etmeleri ve bunların sürekliliği insan faktörüne bağlllık göstermektedir. Başarıya ulaşabilmeleri ancak performansı yüksek çalışanlar ile elde edilebilmektedir (Türk ve Akbaba, 2017:183). Bireylerin fiziksel ya da psikolojik yönden sağlıklı olmaları örgüt içi etkinlik ve performans yönünden dikkat edilmesi gereken konular içerisinde yer almaktadır. Bireylerin sağlıklı olmaları iş tatminlerini artıracak ve performansları yükselecektir. Aksi durum ise çalışanların tatmin düzeylerinin azalması psikolojik sağlıklarının etkilenmesine neden olacak ve bunun sonucunda performanslarında da düşüş meydana gelecektir (Yazıcıŏ̆lu, 2010:244).

Yapılan çalışmalara bakıldığında, çalışanların aşırı iş yükü algılarının iş performanslarını düşürerek işten ayrılma niyetlerini arttıracağı (Çelik ve Çıra, 2013), iş stresi ile performansları arasında doğrusal olmayan ilişki bulunduğu (Saltık, 2016), aynı zamanda örgütsel sağlık ile performans arasında pozitif, iş stresi ile örgütsel sağlık arasında negatif yönlü ilişki tespit edilerek sağlıklı bir yapıya sahip olabilmeleri için örgütlerin iş stresini en az seviyeye indirmeleri ve gereken önlemleri almalarıyla performanslarını olumlu katkı sağlayacağı belirlenmiştir (Gül, 2007). Birey örgüt uyumu ve birey iş uyumu ile iş tatmini, örgütsel aidiyet ve iş performansı arasında pozitif yönlü, iş stresiyle negatif yönlü ilişki olduğu (Kılıç ve Yener, 2015), uyum derecesinin çalışanların örgütsel vatandaşlık davranışı ve iş tatmini ile pozitif yönde ilişkili olduğu (Chin, 2015:1110), birey örgüt uyumunun işte kalma niyeti ve iş performansına pozitif yönde etkisi olduğu (Demir, 2015), kişi örgüt uyumunun mutluluk ve iş performansı ile pozitif etkileşimde olduğu belirlenmiştir (Demirer, 2018).

\section{Sağlık, Güvenlik Uygulamaları ve Covid-19}

Turizm sektöründe faaliyet gösteren işletmelerdeki mevcut çalışma ortamlarında pek çok fiziksel, kimyasal ve biyolojik riskler bulunmakta olup, bu risklerin çalışanlara zarar vermeyecek düzeyde tutulması kapsamında gereken önlemlerin alınması önem arz etmektedir (Çalık ve Demir, 2015:1175). Aynı zamanda sektörde faaliyet gösteren işletmelerde stres ve baskıya neden olan psikososyal tehlikeler de bulunmaktadır (Hoel ve Einarsen, 2003:5). Uzun çalışma saatleri, ücret yetersizliğii, iş yükünün fazlalığı, hafta sonu ve özel günlerde çalışma, akşam ve gece çalışmasının yoğunluğu gibi sektörde bulunan unsurlar çalışanların verimlilik düzeyleri, işe bağlılıkları, işi sahiplenmeleri gibi konularda olumsuz etkiye neden olmaktadır. $\mathrm{Bu}$ unsurlar çalışanları psikososyal anlamda etkilemekte ve çeşitli sağlık sorunlarına neden olabilmektedir (Çalık ve Demir, 2015:1175). Bu kapsamda uygulanan iş sağlığı ve güvenliği; çalışanların işlerini yaptıkları esnada işyerinde mevcut çevre koşullarından kaynaklanan çalışanların karşı karşıya kaldıkları mesleki riskler ve sağlık sorunlarının azaltılması veya yok edilmesi şeklinde ifade edilebilir (Balkır, 2012:58). İnsan sağlı̆ıını ön planda tutan işletmelerin öncelikli olarak personellerinin çalı̧̧ma ortamını sağlıklı ve güvenli hale getirmeleri gerekmektedir (Çavuş ve Biçer, 2019:33). İş sağlı̆̆1 ve güvenliğinin iş verimini de etkileyebildiği düşünüldüğünde güvenli ve sağlıklı bir ortamda çalışabilmenin ancak insan sağlığının göz önüne alınması ile mümkün olduğu, çalışma alanlarının risklerden arındırılmış olmasının önem arz ettiği söylenebilir. Riskleri yok edebilmek için öncelikle mevcut tehlike ve risklerin saptanması ve tekrar oluşumunun engellenmesi gerekmekte olup, alınan önlemler sadece işyerini değil aynı zamanda çevre ve doğayı da ilgilendiren, toplum ekonomisine katkı sağlayan unsurdur (Ateş, 2020:714). Bu kapsamda dünya genelinde etkili olan Covid-19 salgını sonrasında belirlenen kurallar çerçevesinde oluşturulan uygulamaların hem çalışan hem misafir 
sağlığını korumak amacıyla gerçekleştirilmesi gerekmektedir. Bu durumun psikolojik olarak çalışanlar için stres ve baskıya neden olabileceği ve iş verimlerini de etkileyebileceği düşünülmektedir.

Covid-19 salgınını oluşturan virüsün neden olduğu hastalık damlacık yoluyla bulaşmakta ve basit soğuk algınlığı şeklinde olabildiği gibi ağır akut solunum sendromuna kadar değişkenlik gösterebilmektedir. Ortalama kuluçka süresi 5-6 gün (2-14 gün), bazı vakalarda 14 güne kadar uzayabilmektedir. Salgında iş sağlığı ve güvenliği kapsamında en önemli husus olan "önleyici yaklaşım" ilkeleri ile hastalık oluşumunun engellenmesi olmalıdır (Alıcı, Beyan ve Şimşek, 2020:149). Dünyayı etkisi altına alan covid-19 salgını sonrasında işyerlerinin azalan iş gücüyle çalışma durumunda kalmalarının yanı sıra yeni koşullara uyum sağlamalarına yönelik çalışma ortamları oluşturmaları ve mevcut krizden en az zararla atlatabilmek için kriz yönetimi konusunda tecrübeli personel ihtiyacı bulunmaktadır. Salgından korunmaya yönelik ekipmanların yeterli miktarlarda ve uygun fiyatlarda tedariki ilave iş yüküne neden olmaktadır. Süreçlerde meydana gelebilecek aksamalar müşteri, itibar, çalışan memnuniyeti, pazar kaybı risklerini doğuracaktır (Hasanhanoğlu, 2020:13). Turizm sektöründe faaliyet gösteren her işletmenin personellerinin tamamına sağlık eğitimleri verilerek, her çalışanın kendi sağlı̆̆ını korumaya yönelik sorumluluk alması sağlanmalıdır. Çalışanlara verilen bu eğitimlerin içeriğinde hijyen kuralları, bulaşıcı hastalıklar ve korunma yolları, kişisel koruyucu donanımlar ve kullanımı gibi konulara yer verilmelidir. İşyeri hekimliği önemsenmeli ve işe giriş muayeneleri ve periyodik muayeneler düzenli olarak yapılmalıdır. Böylelikle oluşabilecek sorunlar önceden önlenerek işgücü kaybının önüne geçilebilir (İlhan vd., 2017:7). Salgının önlenmesine yönelik yapılan hijyen uygulamaları özellikle ortak kullanım alanlarında önem taşımaktadır. Covid-19 virüsünün insan temasının bulunduğu her yerde hızlıca yayılım gösterdiği bilinmektedir. Bu sebeple ortak kullanılan bütün alanların uygun şekilde temizliğinin yapılması gerekmektedir. İşverenlerin pandemi sürecinde çalışan sağlığını korumaya ilişkin tedbirlerden en önemlisi virüsle mücadele kapsamında alınabilecek bireysel önlemler ile ilgili çalışanları bilgilendirmektir (Ateş, 2020:166). Bireysel olarak mesafe, maske ve hijyen kurallarının uygulanması gerekliliğiyle birlikte turizm sektörüne yönelik yayınlanan genelgelerde mevcut uygulamaların hayata geçirilmesi kapsamında sektörde faaliyet gösteren işletmelerde değişikliklere gidilmiştir. Covid-19 sonrası Kültür ve Turizm Bakanlığı tarafından; Konaklama Tesislerinde Kontrollü Normalleşme Süreci, Yeme İçme Tesislerinde Kontrollü Normalleşme Süreci, Deniz Turizmi Tesis ve Araçları ile Turizm Amaçlı Sportif Faaliyetlerde Kontrollü Normalleşme Süreci, Turist Rehberliği Hizmetinde Kontrollü Normalleşme Süreci ve Kültür ve Sanat Tesislerinde Kontrollü Normalleşme Süreci genelgeleri (tga.gov.tr, 2021) yayınlanmıştır. Yayınlanan genelgeler ve kriterler ile hem misafirler hem de çalışanların sağlı̆̆ını korumaya yönelik pek çok değişiklik ve düzenleme getirilmiştir. Bunun sonucunda işgörenler değişen koşullara adapte olma durumunda kalmış ve yeni çalışma prensipleriyle çalışmaya başlamışlardır. Bu kuralların uygulaması aşamasında çalışanlara büyük görev düşmekte olup durumun kendilerini ne düzeyde etkilediğini belirlemek önem arz etmektedir.

Tatlıcan ve Çöğenli (2020) tarafından yapılan çalışmada; demografik değişkenlere göre iş sağlığı ve güvenliği uygulamalarının çalışanların iş tatmini düzeylerini negatif yönde etkilediği sonucuna ulaşılmıştır. McCaughey, DelliFraine, McGhan ve Bruning (2013) çalışmalarında işyerinden kaynaklanan yaralanma ve hastalıkların, güvenlik iklimi konusundaki zayıf algılarla ilişkili olduğunu ve güvenlik iklimi algılarının, işyerinden kaynaklanan yaralanmalar ile hastalık günleri, iş stresi, işten ayrılma niyeti ve iş tatmini arasındaki ilişkiye aracılık ettiğini belirlemiştir. Aksoy ve Mamatoğlu (2020) yaptıkları çalışma sonucunda; işçi sağlığı ve güvenliğine ilişkin salgın öncesine göre pozitif yönde gelişme olduğunu, işgörenlerin risk algılarında artışın daha güvenli davranmaları yönünde eğilime neden olduğunu tespit etmiştir. 
İnsanların kendilerini güvende hissedebilecekleri yerlere seyahat edeceklerinden ve turistlerde güven hissini oluşturabilecek işletmelerin ülke turizminin geleceğine olumlu katkılar sağlayabileceğinden (Özkoç, 2014:52) hareketle covid-19 salgını düşünüldüğünde bireylerin kendilerini güvende hissedebilmelerinin ancak belirlenen kuralların uygulanması ve kişilerin güven duygusunu edinmeleri ile sağlanabileceği söylenebilir. Bu da insan gücüne dayalı olarak faaliyet gösteren turizm sektöründe ancak çalışanlar ile mümkün olacaktır. Bu kapsamda hem bireysel hem de çalışma alanlarında uygulanması gereken salgından korunmaya yönelik kuralların işleyişinden sorumlu olan çalışanlarda daha fazla iş yükü oluşturmasının yanında kendilerini sosyal ve psikolojik olarak sağlıklı veya güvende hissetmek adına olumlu yönde değişiklikler şeklinde de etkide bulunabileceği düşünülmektedir.

\section{YÖNTEM}

Çalışmada Covid-19 sonrası uygulanan kurallar çerçevesinde sağlık ve güvenlik uygulamalarının işgörenlerin örgüte uyum ve performans düzeyleri üzerindeki etkisinin belirlenmesi amaçlanmıştır. Araştırmanın evreni konaklama tesislerindeki çalışanlar olup, 384 kişi örneklem yeter sayısı olarak belirlenmiştir. Araştırmanın salgın nedeniyle yüz yüze uygulanamıyor olması araştırmanın kısıtlarını oluşturmaktadır. Bu nedenle hazırlanan anket Google anket uygulamasıyla konaklama tesislerinde çalışan 432 işgören üzerinde uygulanmıştır. Anket formu 4 bölümden oluşmaktadır. Anketin ilk bölümünde sağlık ve güvenlik uygulamaların belirlemeye yönelik Üngüren ve Koç (2015) tarafından oluşturulan "İş Sağlığı ve Güvenliği Uygulamaları Performans Değerlendirme Ölçeği"nden covid-19 sonrası yayınlanan Konaklama Tesislerinde Kontrollü Normalleşme Süreci Hakkındaki Genelgeler ve Konaklama Tesisleri Güvenli Turizm Sertifikasyon Kriterleri dikkate alınarak uyarlanmış 5 boyut 32 maddeden oluşan ölçek kullanılmıştır. İkinci bölümde Angel ve Perry (1981) tarafından geliştirilen 4 madde ve tek boyuttan oluşan "Örgüte Uyum Ölçeği", üçüncü bölümde işgören performansını belirlemeye yönelik Kirkman ve Rosen (1999) ve Sigler ve Pearson (2000) tarafından yapılan çalı̧̧malarda kullanılan ve Çöl (2008) tarafından Türkçeye uyarlamış olan toplam 4 ifadeden oluşan ölçek kullanılmıştır. Anketin dördüncü bölümünde ise demografik özelliklerini belirlemeye yönelik ifadeler bulunmaktadır. Araştırma sonucunda demografik özelliklere ilişkin frekans ve yüzde dağılımları, değişkenler arası ilişkileri tespit etmeye yönelik korelasyon ve etkiyi belirlemeye yönelik regresyon analizi yapılmıştır.

\section{Araştırma Modeli ve Hipotezleri}

Araştırma kapsamında belirlenen değişkenler doğrultusunda bir araştırma modeli geliştirilmiştir. Model, yapılan araştırma sonucunda ulaşılması istenen amaca uygun şekilde biçimlendirilmiş olup; elde edilen nicel verilerin rasyonel ve sağlıklı bir şekilde değerlendirilmesi sağlayacaktır (Şekil 1).

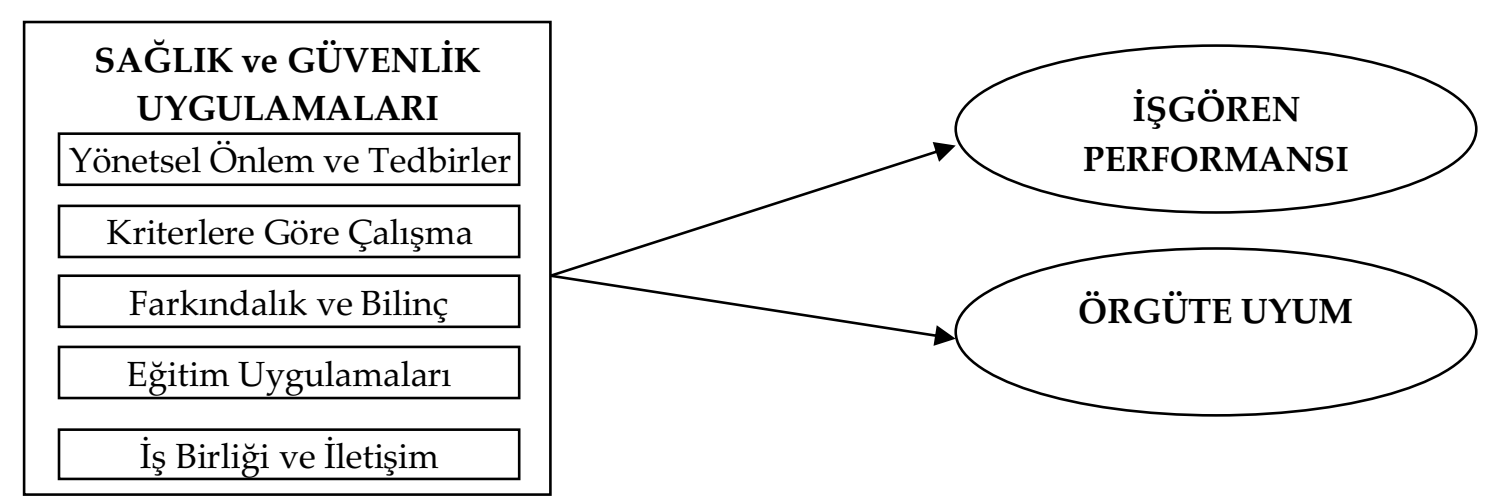

Şekil 1: Araştırmanın Modeli 
Araştırma modelinin çözümlenmesini sağlayacak, araştırmanın kavramsal çerçevesine uygun araştırma hipotezleri oluşturulmuştur. Geliştirilen hipotezler şunlardır:

Hı: Sağlık ve güvenlik uygulamalarının işgören performansı üzerine anlamlı bir etkisi vardır.

Hıa: Yönetsel önlem ve tedbirlerin işgören performansı üzerine anlamlı bir etkisi vardır.

Hıb: Kriterlere göre çalışmanın işgören performansı üzerine anlamlı bir etkisi vardır.

Hı: Farkındalık ve bilincin işgören performansı üzerine anlamlı bir etkisi vardır.

Hıd: Ĕ̆itim uygulamalarının işgören performansı üzerine anlamlı bir etkisi vardır.

Hıe: İş birliği ve iletişimin işgören performansı üzerine anlamlı bir etkisi vardır.

$\mathbf{H}_{2}$ : Sağlık ve güvenlik uygulamalarının örgüte uyum sağlama üzerine anlamlı bir etkisi vardır.

$\mathbf{H}_{2 a}$ : Yönetsel önlem ve tedbirlerin örgüte uyum sağlama üzerine anlamlı bir etkisi vardır.

$\mathbf{H}_{2 b}$ : Kriterlere göre çalışmanın örgüte uyum sağlama üzerine anlamlı bir etkisi vardır.

$\mathbf{H}_{2 c}$ : Farkındalık ve bilincin örgüte uyum sağlama üzerine anlamlı bir etkisi vardır.

$\mathbf{H}_{2 \mathrm{~d}}$ : Eğitim uygulamaların örgüte uyum sağlama üzerine anlamlı bir etkisi vardır.

$\mathrm{H}_{2 e}$ : İş birliği ve iletişimin örgüte uyum sağlama üzerine anlamlı bir etkisi vardır.

\section{BULGULAR}

Yapılan araştırma kapsamında elde edilen veriler ışığında uygun istatistiki analizler gerçekleştirilmiştir.

\section{Ölçeklere İlişkin Güvenilirlik ve Geçerlilik Analizi}

Araştırma çerçevesinde sağlık ve güvenlik uygulamaları ölçeğine faktör analizi uygulanmış ve faktör yapısı araştırılmıştır. Uygulanan faktör analizinde ölçekte yer alan ifadelerin yeterli faktör yükü almalarından dolayı ölçekten hiçbir ifadenin çıkarılmasına gerek duyulmamıştır. Sonraki aşamalarda yapılan analizler 32 ifade üzerinden uygulanmıştır.

Uygulanan faktör analizi sonucuna göre sağlik ve güvenlik uygulamaları ölçeğinde yer alan 32 ifade 5 faktör altında toplamıştır. Faktörler toplam varyansın \%84,49'unu açıklamaktadır. Analiz sonucunda Kaiser-Mayer-Olkin (KMO) örneklem yeterliliğinin \%85,7 olduğu görülmektedir. Ayrıca Bartlett küresellik test değeri, 0,000 düzeyinde anlamlı olup; değer 25343,021 çıkmıştır. Tablo 1'de sağlık ve güvenlik uygulamaları ölçeğine uygulanan faktör analizi sonuçlarına yer verilmiştir.

Tablo 1. Sağlık ve Güvenlik Uygulamaları Ölçeği Faktör Analizi Sonuçları

FAKTÖRLER

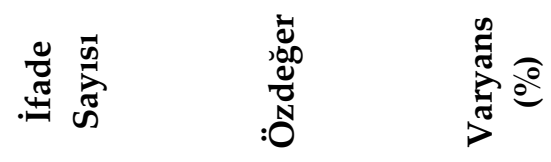

\begin{tabular}{llll}
\hline Yönetsel Önlem ve Tedbirler & 9 & 7,939 & 24,811 \\
\hline Kriterlere Göre Çalışma & 6 & 6,208 & 19,399 \\
\hline Farkındalık ve Bilinç & 6 & 6,174 & 19,295 \\
\hline Ĕgitim Uygulamaları & 6 & 5,196 & 16,238 \\
\hline İş Birliği ve İletişim & 5 & 1,519 & 4,748 \\
\hline
\end{tabular}

Açıklanan Toplam Varyans: \%84,49;Kaiser-Meyer-Olkin örneklem yeterliliği: \%85,7;

Bartlett küresellik testi: X2: 25343,021; s.d.: 496, p<0.000; 
Faktör analizi sonucunda ulaşılan birinci faktör, 9 ifadeden oluşmaktadır. Faktörün toplam varyansın \%24,811'ini açıkladığı görülmektedir. Birinci faktör altında yer alan ifadeler incelenmiş ve bu faktör "Yönetsel Önlem ve Tedbirler" olarak isimlendirilmiştir. Faktör analizi sonucu, ulaşılan ikinci faktör ise 6 ifadeden oluşmaktadır. İkinci faktörün toplam varyansın \%19,399'unu açıladığı görülmekte. Altı İfadeden oluşan faktör "Kriterlere Göre Çalışma" olarak isimlendirilmiştir. Uygulanan faktör analizi sonucunda ulaşılan üçüncü faktör de 6 ifadeden oluşmakta ve toplam varyansın \%19,295'ini açıkladığı görülmektedir. Üçüncü faktör ifadeleri incelenerek "Farkındalık ve Bilinç" olarak isimlendirilmiştir. Dördüncü faktör, toplam varyansın \%16,238'ini açıklamakta ve 6 ifadeden meydana gelmektedir. Dördüncü faktör ifadeleri de incelenmiş ve "Eğitim Uygulamaları" olarak isimlendirilmiştir. Yapılan faktör analizi sonucunda sağlık ve güvenlik uygulamaları ölçeğinden ulaşılan son faktör 5 ifadeden meydana gelmekte ve toplam varyansın \%4,748'ini açıkladığ görülmektedir. Beşinci faktör ifadeleri de incelenmiş ve "İş Birliği ve İletişim" olarak isimlendirilmiştir.

Araştırma çerçevesinde işgören performansı ölçeğine faktör analizi uygulanmış ve faktör yapısı incelenmiştir. 4 ifade üzerinde yapılan faktör analizi sonucunda ifadelerin faktör yükünün yeterli olduğu ve bu nedenle ifadelerinin ölçekten çıkarılmamasına karar verilmiştir. Böylece analizlere yine ölçeği oluşturan 4 ifade üzerinden devam edilmiştir.

Uygulanan faktör analizi sonucunda işgören performans ölçeğinde yer alan 4 ifade tek faktör altında toplamıştır. Faktör toplam varyansın \%82,70'ini açıkladığı görülmektedir. Analiz sonucunda Kaiser-Mayer-Olkin (KMO) örneklem yeterliliğini \%81,1 olduğu tespit edilmiştir. Ayrıca Bartlett küresellik test değeri, 0,000 düzeyinde anlamlı olup; değer 1454.016 çıkmıştır. Tablo 2'deişgören performansı ölçeğine yapılan faktör analizi sonuçlarına yer verilmiştir.

Tablo 2. İşgören Performansı Ölçeği Faktör Analizi Sonuçları

\begin{tabular}{|c|c|c|c|}
\hline FAKTÖRLER & 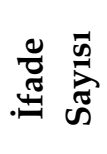 & 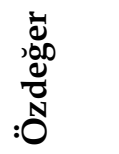 & 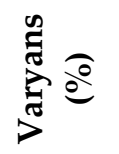 \\
\hline İşgören Performansı & 4 & 3,308 & 82,702 \\
\hline
\end{tabular}

Genel Açıklanan Toplam Varyans: \%82,70; Kaiser-Meyer-Olkin örneklem yeterliliği: \%81,1; Bartlett küresellik testi: $X^{2}$ : 1454,016; s.d.: 6, p<0.000;

Araştırma kapsamında örgüte uyum sağlama ölçeğine faktör analizi uygulanmış ve 4 ifade üzerinde uygulanan faktör analizinde ifadelerin tamamının faktör yükünün yeterli olduğu saptanmiştır.

Uygulanan faktör analizi sonucunda örgüte uyum ölçeğinde yer alan 4 ifade tek faktör altında toplamıştır. Faktör toplam varyansın \%83,62'sini açıkladığı görülmektedir. Analiz sonucunda Kaiser-Mayer-Olkin (KMO) örneklem yeterliliğini \%79,4 olduğu tespit edilmiştir. Ayrıca Bartlett küresellik test değeri, 0,000 düzeyinde anlamlı olup; değer 1601,842 çıkmıştır. Tablo 3'de örgüte uyum sağlama ölçeğine yapılan faktör analizi sonuçlarına yer verilmiştir.

$\mathrm{Bu}$ bağlamda araştırma dâhilinde oluşturulan sağlık ve güvenlik uygulamaları, işgören performansı ve örgüte uyum sağlama ölçeklerine güvenirlik analizi uygulanmıştır. Araştırmaya katılanlara uygulanmış olan ölçeklerin güvenirlilik katsayıları: sağlık ve güvenlik uygulamaları ölçeği güvenirlilik katsayısı, Alpha $(\alpha)=0,97$; işgören performansı ölçeğinin güvenirlilik katsayısı, Alpha $(\alpha)=0,93$; örgüte uyum sağlama ölçeğinin güvenirlilik katsayısı, Alpha 
$(\alpha)=0,93^{\prime}$ dür. Elde edilen bulgulara göre, çalışmada kullanılan ölçümlerin yüksek derecede güvenilir olduğu söylenebilir. Tablo 4'te güvenirlilik analizi sonuçlarına yer verilmiştir.

Tablo 3. Örgüte Uyum Ölçeği Faktör Analizi Sonuçları

\begin{tabular}{|c|c|c|c|}
\hline FAKTÖRLER & 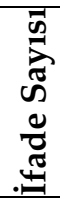 & 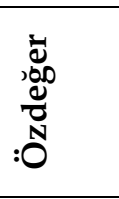 & 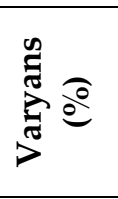 \\
\hline Örgüte Uyum Sağlama & 4 & 3,345 & 83,626 \\
\hline
\end{tabular}

Genel Açılanan Toplam Varyans: \%83,62; Kaiser-Meyer-Olkin örneklem yeterliliği: \%79,4;

Bartlett küresellik testi: $X^{2}: 1601,842$; s.d.: 6, p<0.000;

Tablo 4. Ölçümlerin Güvenirlik Katsayıları

\begin{tabular}{lcc}
\hline \multicolumn{1}{c}{ Ölçekler } & Cronbach's Alpha & İfade sayısı (N) \\
\hline Sağlık ve Güvenlik Uygulamaları & $\mathbf{0 , 9 7}$ & $\mathbf{3 2}$ \\
\hline Yönetsel Önlem ve Tedbirler & 0,97 & 9 \\
\hline Kriterlere Göre Çalışma & 0,96 & 6 \\
\hline Farkındalık ve Bilinç & 0,92 & 6 \\
\hline Eğitim Uygulamaları & 0,95 & 5 \\
\hline İş Birliği ve İletişim & 0,93 & $\mathbf{4}$ \\
\hline İşgören Performansı & $\mathbf{0 , 9 3}$ & $\mathbf{4}$ \\
\hline Örgüte Uyum sağlama & $\mathbf{0 , 9 3}$ & \\
\hline
\end{tabular}

\section{Demografik Özelliklere İlişkin Bulgular}

Araştırmaya dahil olan katılımcıların demografik özelliklerini belirlemek adına betimleyici istatistiklerden frekans ve yüzde analizleri uygulanmıştır. Tablo 5 'te katılımcılara ilişkin demografik özellikler detaylandırılmıştır.

Tablo 5'e göre katılımcıların \%54,2'si kadın (n:234), \%45,8'i erkek (n:198), \%44,4'ü 21-30 yaş aralığında (n:192), \%31,9'u 31-40 yaş aralığında (n:138), \%54,2'si evli(n:234) ve \%45,8'ibekârdır (n:198). Katılımcıların eğitim durumlarına bakıldığında ise büyük çoğunluğun önlisans (\%25,0; n:108), lisans (\%40,3; n:174) ve lisanüstü (\%23,6; n:102) düzeylerinde oldukları görülmektedir. Katılımcların çalıştıkları departmanları incelendiğinde, \%15,3'ününönbüro (n: 66), \%33,3'ünün yiyecek-içecek (n:144), \%9,7'sinin kat hizmetleri (n: 42), \%12,5'inin insan kaynakları (n:54), $\% 9,7^{\prime} \operatorname{sinin}$ satış pazarlama (n:42), \%13,9'unun muhasebe (n:60), \%4,2'sinin teknik servis (n:18) ve \%1,4'ünün de diğer departmanlarda görev aldıkları görülmektedir. Katılımcıların çalışma sürelerine göre dağılımları incelendiğinde, \%41,7'sinin 0-5 yıl arasında (n:180), \%40,3'ünün 6-10 yıl arasında (n:174), \%12,5'inin 11-15 yıl arasında (n:54) ve \%5,6'sınınise 15 yıl ve üzeri (n:24) süre ile meslekte çalıştıkları tespit edilmiştir. 
Tablo 5. Katılımcıların Kişisel Özelliklerine İlişkin Bulgular

\begin{tabular}{|c|c|c|c|}
\hline Değişkenler & & $\mathrm{f}$ & $\%$ \\
\hline \multirow[t]{2}{*}{ Cinsiyet } & Kadın & 234 & 54,2 \\
\hline & Erkek & 198 & 45,8 \\
\hline \multirow{5}{*}{ Yaş } & 20 ve altı yaş & 6 & 1,4 \\
\hline & $21-30$ yaş arası & 192 & 44,4 \\
\hline & $31-40$ yaş arası & 138 & 31,9 \\
\hline & $41-50$ yaş arası & 90 & 20,8 \\
\hline & 51 ve üzeri yaş & 6 & 1,4 \\
\hline \multirow[t]{2}{*}{ Medeni durum } & Bekar & 237 & 54,2 \\
\hline & Evli & 198 & 45,8 \\
\hline \multirow{5}{*}{ Eğitim durumu } & İlköğretim & 6 & 1,4 \\
\hline & Lise & 42 & 9,7 \\
\hline & Önlisans & 108 & 25,0 \\
\hline & Lisans & 174 & 40,3 \\
\hline & Lisansüstü & 102 & 23,6 \\
\hline \multirow{8}{*}{ Departman } & Önbüro & 66 & 15,3 \\
\hline & Yiyecek-İçecek & 144 & 33,3 \\
\hline & Kat Hizmetleri & 42 & 9,7 \\
\hline & Muhasebe & 60 & 13,9 \\
\hline & Teknik Servis & 18 & 4,2 \\
\hline & Satış Pazarlama & 42 & 9,7 \\
\hline & İnsan Kaynakları & 54 & 12,5 \\
\hline & Diğer & 6 & 1,4 \\
\hline \multirow{4}{*}{ Çalışma Süresi } & $0-5$ y1l & 180 & 41,7 \\
\hline & $6-10$ yil & 174 & 40,3 \\
\hline & $11-15$ y1l & 54 & 12,5 \\
\hline & 16 yıl ve üzeri & 24 & 5,6 \\
\hline \multicolumn{2}{|l|}{ Toplam } & 432 & 100,00 \\
\hline
\end{tabular}

\section{Değişkenlere İlişkin Tanımlayıcı İstatistikler}

Araştırma kapsamında ölçülmesi amaçlanan değiş̧enlere ve alt boyutlarına yönelik genel ortalama ve standart sapma değerleri Tablo 6'da detaylandırılmıştır.

Tablo 6. Değişkenlere İlişkin Aritmetik Ortalama ve Standart Sapma Değerleri

\begin{tabular}{lcc}
\hline \multicolumn{1}{c}{ Ölçekler } & $\begin{array}{c}\text { Aritmetik } \\
\text { Ortalamalar }\end{array}$ & Standart Sapma \\
\hline Sağlık ve Güvenlik Uygulamaları & $\mathbf{3 , 6 9}$ & $\mathbf{, 8 0}$ \\
\hline Yönetsel Önlem ve Tedbirler & 3,84 &, 81 \\
\hline Kriterlere Göre Çalışma & 3,57 &, 92 \\
\hline Farkındalık ve Bilinç & 3,59 &, 81 \\
\hline Eğitim Uygulamaları & 3,67 &, 85 \\
\hline İş Birliği ve İletişim & 3,69 &, 71 \\
\hline İşgören Performansı & $\mathbf{3 , 9 7}$ & $\mathbf{7 9}$ \\
\hline Örgüte Uyum sağlama & $\mathbf{3 , 6 9}$ & $\mathbf{8 0}$ \\
\hline
\end{tabular}


Genel olarak katılımcıların sağlık ve güvenlik uygulamaları algıları düzeyi incelendiğinde ortalama üzeri sonuçlar ile karşılaşılmaktadır $(X=3,69 ; \quad s s=0,80)$. Boyutlar bazında incelendiğinde yönetsel önlem ve tedbirler boyutu $(X=3,84 ; s s=0,81)$, kriterlere göre çalışma boyutu $(X=3,57 ; \mathrm{ss}=0,92)$, farkındalık ve bilinç boyutu $(X=3,59$; $s \mathrm{~s}=0,81)$, eğitim uygulamaları boyutu $(X=3,67$; $s s=0,85)$ ve iş birliği ve iletişim boyutu $(X=3,69$; $s s=0,71)$ ortalamalara sahip olduğu görülmektedir. İşgören performansı düzeyi $(X=3,97 ; \mathrm{ss}=0,79)$ ve örgüte uyum sağlama düzeyine $(X=3,69$; ss=0,80) bakıldığında sağlık ve güvenlik uygulamalarında olduğu gibi ortalamanın üzerinde sonuçlar olduğu tespit edilmiştir.

\section{Değişkenlerarası İlişkilere Yönelik Korelasyon Analizi Sonuçları}

Konaklama işletmeleri işgörenlerinin sağlık ve güvenlik uygulamaları, örgüte uyum sağlama ve işgören performansı düzeyleri arasındaki ilişkileri belirlemek amacıyla uygulanan korelasyon analizinin sonuçları Tablo 7'de detaylandırılmıştır.

Tablo 7. Sağlık ve Güvenlik Uygulamaları, İşgören Performansı ve Örgüte Uyum Sağlama İlişkisine Yönelik Korelasyon Katsayıları

\begin{tabular}{|c|c|c|c|c|c|c|c|c|}
\hline & (1) & (2) & (3) & $(4)$ & (5) & (6) & (7) & (8) \\
\hline $\begin{array}{l}\text { Genel Sağlık ve Güvenlik } \\
\text { Uygulamaları (1) }\end{array}$ & 1 & & & & & & & \\
\hline Yönetsel Önlem ve Tedbirler (2) &, $825^{* *}$ & 1 & & & & & & \\
\hline Kriterlere Göre Çalışma (3) & $863^{* *}$ & $635^{* *}$ & 1 & & & & & \\
\hline Farkındalık ve Bilinç (4) & ,912** & ,614* & $810^{* *}$ & 1 & & & & \\
\hline Eğitim Uygulamaları (5) & $836^{* *}$ &, $538^{* *}$ & $636^{* *}$ & $726^{* *}$ & 1 & & & \\
\hline İş Birliği ve İletişim (6) & $858^{* *}$ &, $588^{* *}$ & $602^{* *}$ & $851^{* *}$ & ,772** & 1 & & \\
\hline İşgören Performansı (7) & ,619** & ,330* &, $565^{* *}$ & ,639** &, $593^{* *}$ & ,632** & 1 & \\
\hline Örgüte Uyum Sağlama (8) & ,710 & $458^{* *}$ &, $565^{* *}$ & , $707^{* *}$ & ,612 & $822^{* *}$ & ,694 & 1 \\
\hline
\end{tabular}

** Korelasyon $(\mathrm{p}<0.01),{ }^{*}$ Korelasyon $(\mathrm{p}<0.05)$ seviyesinde anlamlı (2-uçlu). $\mathrm{N}=432$

Araştırma kapsamında uygulanan korelasyon analizinde, sağlık ve güvenlik uygulamaları değişkenini oluşturan boyutlar ile işgören performansı ve örgüte uyum sağlama arasında genel olarak orta ve yüksek düzeyde anlamlı ve pozitif yönlü bir ilişki olduğu tespit edilmiştir. Sağlık ve güvenlik uygulamalarının yönetsel önlem ve tedbirler boyutunun, işgören performansı $(\mathrm{r}=0,330)$ ve örgüte uyum sağlama $(\mathrm{r}=0,458)$ ile arasında anlamlı ve pozitif yönlü ilişki bulunmaktadır. Kriterlere göre çalışma boyutunun, işgören performansı $(\mathrm{r}=0,565)$ ve örgüte uyum sağlama $(r=0,565)$ ile arasında anlamlı ve pozitif yönlü ilişki içerisinde olduğu görülmektedir. Farkındalık ve bilinç boyutunun, işgören performansı $(r=0,639)$ ve örgüte uyum sağlama $(r=0,707)$ ile arasında anlamlı ve pozitif yönlü ilişkisi vardır. Eğitim uygulamaları boyutunun, işgören performansı $(r=0,593)$ ve örgüte uyum sağlama $(r=0,612)$ ile arasında anlamlı ve pozitif yönlü ilişki bulunmaktadır. Analiz sonuçlarına göre iş birliği ve iletişim boyutunun da işgören performansı $(\mathrm{r}=0,632)$ ve örgüte uyum sağlama $(\mathrm{r}=0,822)$ ile arasında anlamlı ve pozitif yönlü ilişki tespit edilmiştir. Son olarak genel sağlık ve güvenlik uygulamaları, işgören performansı $(\mathrm{r}=0,619)$ ve örgüte uyum sağlama $(\mathrm{r}=0,710)$ ile arasında anlamlı ve pozitif yönlü ilişki tespit edilmiştir. Bu bilgiler ışığında sağlık ve güvenlik uygulamaları artması durumunda işgören performansı ve örgüte uyum sağlama düzeylerinin de artacağını söylemek mümkündür. 


\section{Değişkenlerarası Uygulanan Regresyon Analizi Sonuçları ve Hipotez Testleri}

Sağlık ve güvenlik uygulamalarının işgören performansı üzerinde etkisini belirlemeye yönelik çoklu regresyon analizi uygulanmıştır. Tablo $8^{\prime}$ de sağlık ve güvenlik uygulamalarının işgören performansı düzeyleri üzerine etkisini inceleyen çoklu regresyon analizi sonuçları detaylandırılmıştır

Tablo 8. Sağlık ve Güvenlik Uygulamalarının_İşgören Performansı Üzerine Etkisini İnceleyen Çoklu Regresyon Analizi

\begin{tabular}{llllll}
\hline BAĞIMSIZ DEĞİŞKENLER & & & & \\
& BETA & T & SiG. (P) & Tolerance & VíF \\
\hline Yönetsel Önlem ve Tedbirler &,- 231 & $-4,852$ &, $000^{* *}$ &, 528 & 1,895 \\
\hline Kriterlere Göre Çalışma &, 304 & 4,465 &, $000^{* *}$ &, 257 & 3,895 \\
\hline Farkındalık ve Bilinç &, 091 &, 974 &, 330 &, 136 & 7,369 \\
\hline Ĕgitim Uygulamaları &, 162 & 2,797 &, $005^{* *}$ &, 357 & 2,804 \\
\hline İş Birliği ve İletişim &, 382 & 4,741 &, $000^{* *}$ &, 184 & 5,448 \\
\hline $\mathbf{F}$ & 82,412 & & & & \\
\hline $\mathbf{R}$ &, 701 & & & \\
\hline $\mathbf{R}^{2}$ &, 492 & & \\
\hline Adjusted $\mathbf{R}^{2}$ &, 486 & & \\
\hline Durbin-Watson & 1,814 & & \\
\hline${ }^{*}$ Değer 0,05 düzeyinde anlamlıdır ${ }^{* *}$ Değer 0,01 düzeyinde anlamlıdır \\
\hline
\end{tabular}

İşgören Performansı= f (Yönetsel Önlem ve Tedbirler, Kriterlerine Göre Çalışma, Farkındalık ve Bilinç, Eğitim Uygulamaları, İş Birliği ve İletişim)

Model işgören performansı düzeyi değişiminin \%48,6 (adjusted R²)'sını açıklamaktadır. Diğer bir ifadeyle, konaklama işletmeleri çalışanlarının sağlık ve güvenlik uygulamaları işgören performansı düzeylerindeki değişimin $\% 48,6$ 'sını açıklamaktadır. Tablo 8'e göre, kriterlere göre çalışma, eğitim uygulamaları ve iş birliği ve iletişimin işgören performansına olan etkisinin pozitif ve doğrusal yönlü olduğu sonucuna ulaş1lırken, yönetsel önlem ve tedbirler boyutunun işgören performansı üzerindeki etkisinin anlamlı ve negatif yönlü olduğu tespit edilmiştir. Sağlık ve güvenlik uygulamalarının farkındalık ve bilinç boyutunun ise işgören performansı üzerine herhangi anlamlı bir etkisinin olmadığı belirlenmiştir. Ulaşılan bulgular doğrultusunda kriterlere göre çalışma puanının bir birim artması işgören performansı puanının 0,304 (Beta1) kadar artacağını, eğitim uygulamaları puanının bir birim artması durumunda işgören performansı puanının 0,162 (Beta') kadar artacağını ve iş birliği ve iletişim puanının bir birim artması durumunda işgören performansı puanının 0,382 (Beta') kadar artacağını söylemek mümkündür. Ayrıca yönetsel önlem ve tedbirler puanının bir birim artması durumunda işgören performansı puanını -0,231 (Beta1 ${ }^{1}$ kadar azaltacağını söylemek mümkündür. Farkındalık ve bilinç boyutunun işgören performansı üzerinde anlamlı bir etkisi olduğu sonucuna ulaşılamamıştır. Bu bilgiler 1şığında $\mathrm{H}_{1}$ hipotezini, $\mathrm{H}_{1 \mathrm{a}}, \mathrm{H}_{1 \mathrm{~b}}, \mathrm{H}_{1 \mathrm{c}}, \mathrm{H}_{1 d}$ ve $\mathrm{H}_{1 e}$ alt hipotezlerini test etmeye yönelik belirlenen regresyon modeli $\mathrm{H}_{1}$ hipotezini destekler nitelikte olduğu görülmektedir. Bunun dişında $\mathrm{H}_{1 a}, \mathrm{H}_{1 b}, \mathrm{H}_{1 d}$ ve $\mathrm{H}_{1 e}$ alt hipotezleri kabul edilmiş, fakat $\mathrm{H}_{1 \mathrm{c}}$ alt hipotezi reddedilmiştir.

Araştırmanın bu bölümünde sağlı ve güvenlik uygulamaları ölçeğinin her bir boyutunun, örgüte uyum sağlama üzerinde anlamlı bir etkisi olup olmadığını belirlemeye yönelik çoklu regresyon analizi yapılmıştır. Tablo $9^{\prime}$ da sağlık ve güvenlik uygulamalarının örgüte uyum sağlama düzeyleri üzerine etkisini inceleyen çoklu regresyon analizi sonuçları detaylandırılmıştır 
Tablo 9. Sağlık ve Güvenlik Uygulamalarının Örgüte Uyum Sağlama Üzerine Etkisini İnceleyen Çoklu Regresyon Analizi

\begin{tabular}{llllll}
\hline BAĞIMSIZ DEĞİ̧SKENLER & BETA & T & SïG. (P) & Tolerance & ViF \\
\hline Yönetsel Önlem ve Tedbirler &,- 112 & $-3,071$ &, $002^{* *}$ &, 528 & 1,895 \\
\hline Kriterlere Göre Çalışma &, 293 & 5,606 &, $000^{* *}$ &, 257 & 3,895 \\
\hline Farkındalık ve Bilinç &,- 215 & $-2,994$ &, $003^{* *}$ &, 136 & 7,369 \\
\hline Eğitim Uygulamaları &,- 122 & $-2,755$ &, $006^{* *}$ &, 357 & 2,804 \\
\hline İş Birliği ve İletişim &, 989 & 15,996 &, $000^{* *}$ &, 184 & 5,448 \\
\hline $\mathbf{F}$ & 199,595 & & & & \\
\hline $\mathbf{R}$ &, 837 & & & \\
\hline $\mathbf{R}^{2}$ &, 701 & & & \\
\hline Adjusted R & $, 69,7$ & & \\
\hline Durbin-Watson & 1,712 & & \\
\hline${ }^{*}$ Değer 0,05 düzeyinde anlamlıdır ** Değer 0,01 düzeyinde anlamlıdır
\end{tabular}

${ }^{*}$ Değer 0,05 düzeyinde anlamlıdır ${ }^{* *}$ Değer 0,01 düzeyinde anlamlıdır

Örgüte Uyum Sağlama = f (Yönetsel Önlem ve Tedbirler, Kriterlerine Göre Çalışma, Farkındalık ve Bilinç, Eğitim Uygulamaları, İş Birliği ve İletişim)

Model örgüte uyum sağlama düzeyi değişiminin \%69,7 (adjusted $\mathrm{R}^{2}$ )'sini açıklamaktadır. Diğer bir ifadeyle, konaklama tesisi çalışanlarının sağlık ve güvenlik uygulamaları örgüte uyum sağlama düzeylerindeki değiş̧imin \%69,7'sini açılamaktadır. Tablo 9'a göre, kriterlere göre çalışma ve iş birliği ve iletişimin örgüte uyum sağlamaya olan etkisinin pozitif ve doğrusal yönlü olduğu sonucuna ulaşılırken, yönetsel önlem ve tedbirler, farkındalık ve bilinç ve eğitim uygulamaları boyutlarının örgüte uyum sağlama üzerindeki etkisinin anlamlı ve negatif yönlü olduğu tespit edilmiştir. Elde edilen bulgular doğrultusunda kriterlere göre çalışma puanının bir birim artması durumunda örgüte uyum sağlama puanının 0,293 (Beta1) kadar artacağını ve iş birliği ve iletişim puanının bir birim artması durumunda örgüte uyum sağlama puanının 0,989 $\left(\right.$ Beta $\left.^{1}\right)$ kadar artacağını söylemek mümkündür. Ayrıca yönetsel önlem ve tedbirler puanının bir birim artması durumunda örgüte uyum sağlama puanını-0,112 (Beta1) kadar azaltacağını, farkındalık ve bilinç puanının bir birim artması durumunda örgüte uyum sağlama puanının -0,215 (Beta $\left.{ }^{1}\right)$ kadar azaltacağını ve eğitim uygulamaları puanının bir birim artması durumunda örgüte uyum sağlama puanının -0,122 (Beta1 ${ }^{1}$ kadar azaltacağını söylemek mümkündür. Bu bilgiler 1şığında $\mathrm{H}_{2}$ hipotezini, $\mathrm{H}_{2 a}, \mathrm{H}_{2 b}, \mathrm{H}_{2 c}, \mathrm{H}_{2 \mathrm{~d}}$ ve $\mathrm{H}_{2 e}$ alt hipotezlerini test etmeye yönelik belirlenen regresyon modelinin $\mathrm{H}_{2}$ hipotezini destekler nitelikte olduğu görülmektedir. Bunun dışında $\mathrm{H}_{2 a}, \mathrm{H}_{2 b}, \mathrm{H}_{2 c}, \mathrm{H}_{2 \mathrm{~d}}$ ve $\mathrm{H}_{2 \mathrm{e}}$ alt hipotezleri de kabul edilmiştir.

\section{SONUÇ}

Turizm sektöründe çalışanların sağlıklı ve güvenli bir ortamda bulunmaları, bu ortamın oluşturulmasına ilişkin belirlenen değişiklikler veya uygulamalara uyum sağlamaları ve gerçekleştirilen uygulamaların performanslarını olumlu yönde etkilemesi işletmelerin başarısı ve hizmet kalitesinin artırılmasında önemli bir rol oynamaktadır. Bu kapsamda Covid-19 sonrası uygulamalar ve çalışanların uyum sağlama düzeyleri ve performansları üzerinde etkinin belirlenmesine yönelik yapılan araştırma önemlidir. Bu kapsamda konaklama işletmesinde çalışan işgörenlerin Covid-19 sonrasında gerekli olan sağlık ve güvenlik uygulamaları ve bu uygulamaların örgüte uyum ve performanslarına etkisi belirlemeye yönelik yapılan çalışma sonucunda örgüte uyum düzeylerinin 3,69, işgören performans düzeylerinin 
3,79, sağlık ve güvenlik uygulamalarının ise 3,69 ile oldukça yüksek değerler aldığ görülmektedir.

Değişkenler arası ilişkileri belirlemeye yönelik yapılan korelasyon analizine göre sağlık ve güvenlik boyutları olan yönetsel önlem tedbirler, kriterlere göre çalışma, farkındalık ve bilinç, eğitim uygulamaları, iş birliği ve iletişim alt boyutları ile işgören performansı ve örgüte uyum arasında anlamlı ve pozitif yönlü ilişki saptanmıştır. Bu kapsamda işletmede uygulanan sağlık ve güvenlik uygulamaları arttıkça işgörenlerin örgüte uyum ve performanslarının artacağını söylemek mümkündür.

Değişkenler arası etkiyi belirlemeye yönelik yapılan çoklu regresyon analizine göre sağlık ve güvenlik uygulamaları alt boyutlarının işgören performansındaki değişimin \%48,6'sını açıkladığı görülmektedir. Yönetsel önlem ve tedbirler alt boyutunun işgören performansını anlamlı negatif yönde etkilediği, kriterlere göre çalışma, eğitim uygulamaları, iş birliği ve iletişim alt boyutlarının işgören performansını anlamlı ve pozitif yönde etkilediği, farkındalık ve bilinç alt boyutunun ise işgören performansı üzerinde anlamlı bir etkiye neden olmadığı belirlenmiştir. Örgüte uyuma ilişkin etkiyi belirlemeye yönelik yapılan analiz sonucunda ise sağlık ve güvenlik uygulamalarının örgüte uyum sağlama düzeyindeki değişimin $\% 69,7^{\prime}$ sini açıkladığı, saptanmıştır. Yönetsel önlem ve tedbirler, farkındalık ve bilinç, eğitim uygulamaları alt boyutlarının örgütsel uyumu anlamlı ve negatif yönde etkilediği, kriterlere göre çalışma, iş birliği ve iletişim boyutlarının ise örgüte uyumu anlamlı ve pozitif yönde etkilediği belirlenmiştir. Yapılan araştırma sonucunda sağlık ve güvenlik uygulamalarının iş gören performansını ve çalışanların bulundukları örgüte uyum sağlama düzeylerini önemli düzeyde açıkladığı görülmüştür. Sağlık ve güvenlik uygulamalarında yönetsel olarak alınan önlem ve tedbirler çalışanlar tarafından olumsuz bir durum şeklinde algılanmakta ve bununla beraber performanslarına da olumsuz şekilde yansımaktadır. Benzer şekilde sağlık ve güvenlik uygulamaları kapsamında yönetimin aldığı önlem ve tedbirler ile birlikte çalışanlara verilen eğitimler, çalışanların örgüte uyum sağlama süreçlerine olumsuz yansımaktadır. Farkındalık ve bilinç çalışmalarının çalışanların örgüte uyum sağlama düzeylerini negatif yönde etkilemesi yine dikkat çeken sonuçlar arasındadır.

Yapılan araştırmaya göre covid-19 salgını sonrasında uygulanan sağlık ve güvenlik uygulamalarının yüksek düzeyde olduğu ve uygulamaların çalışanların örgüte uyum ile performansları üzerinde etkili olduğu söylenebilir. Araştırma sonuçlarına göre işletmelerde uygulanan yönetsel anlamdaki sağlık ve güvenlik önlemlerinin çalışanların örgüte uyum sağlamaları ve performanslarını negatif yönde etkilediği sonucundan hareketle alınan önlemlerin kendi sağlıkları ve misafirlerin sağlığı açısından uygulandığına yönelik bilinç oluşturulması önerilmektedir. Böylelikle iş yerlerinde bir güvenlik kültürü oluşturularak çalışanların negatif yönde örgüte uyumu ve performans sergileme eğilimleri azaltılabilir.

Sağlık ve güvenlik kapsamında uygulanan eğitim uygulamaları ile farkındalık ve bilinç düzeylerinin de örgüte uyum sağlama düzeylerini negatif yönde etkiliyor olmasının nedenlerinin araştırılması, bu uygulamaların kendileri için bir iş yükü oluşturmanın aksine onlar açısından faydalı bilgileri kapsadığının hizmet içi eğitimler ile aktarılması önerilmektedir.

İlerleyen dönemlerde aşı çalışmalarının tamamlanmasının ardından araştırmanın tekrar edilmesi ve kavramların iş stresi, iş tatmini, örgüt kültürü, işe yabancılaşma, örgütsel bağlılık, pozitif psikolojik sermaye gibi farklı değişkenler üzerinde etkisini ölçülmesi önerilmektedir.

Ayrıca araştırma turizm sektörü çalışanları üzerinde uygulanmıştır. Birçok sektörde uygulanabileceği düşünüldügünden farklı sektör ve zaman aralıklarında tekrar edilmesi önerilmektedir. 


\section{KAYNAKLAR}

Aksoy, Ş. ve Mamatoğlu, M. (2020). Covid-19 Salgın Döneminde Örgütlerde Güvenlik İkliminin İş Güvenliği Uzmanları Perspektifinden Değerlendirilmesi, Avrasya Sosyal ve Ekonomi Araştırmaları Dergisi, 7(5): 26-37.

Alaeddinoğlu, F. ve Rol, S. (2020). Covid-19 Pandemisi ve Turizm Üzerindeki Etkileri. Yüzüncü Yıl Üniversitesi Sosyal Bilimler Enstitüsü Dergisi, (Salgın Hastalıklar Özel Sayıs1), 233-258.

Alıcı, N. Ş., Beyan, A. C. ve Şimşek, C. (2020). Meslek Hastalığ Olarak COVID-19, Eurasian J Pulmonol, Ek sayı: 148-165.

Angel, H. L. and Perry J. L. (1981). An Empirical Assessment of Organizational Commitment and Organizational Effectiveness, Administrative Science Quarterly, 26(1): 1-14.

Ateş, Z. G. (2020). Çalışanların İş Sağlığı ve Güvenliği Açısından Eğitilmeleri, Selçuk Üniversitesi Hukuk Fakültesi Dergisi, 28(2): 713-745.

Balkır, Z. (2012). İş Sağlığı ve Güvenliği Hakkının Korunması: İşverenin İş Sağlığı ve Güvenliği, Sosyal Güvenlik Dergisi, 2(1): 56-91.

Bhattacharya, M., Gibson, D., and Doty, D. H. (2005). The Effects of Flexibility in Employee Skills, Employee Behaviors, and Human Resource Practices on Firm Performance, Journal of Management, 31(4): 622-640.

Chin, T. (2015). Harmony and Organizational Citizenship Behavior in Chinese Organizations, The International Journal of Human Resource Management, 26(8): 1110-1129.

Çalık, İ. ve Demir. O. (2015). İş Sağlığı ve Güvenliği Kapsamında Konaklama ve Yiyecek-İçecek İşyerlerinde Psikososyal Riskler, Uluslararası Sosyal Araştırmalar Dergisi, 8(41): 1170-1177.

Çalık, T. (2003). İşgörenlerin Örgüte Uyumu (Örgütsel Sosyalizasyon), Türk Eğitim Bilimleri Dergisi, 1(2): 163-177.

Çavuş, M. F. ve Biçer, M. (2019). İnsan Kaynakları Yönetimi Çerçevesinde Sosyalleşmek ya da Yabancılaşmak. (1. Baskı), Ankara: Gazi Kitabevi.

Çelik, M. ve Çıra, A. (2013). Vatandaşlık Davranışının İş Performansı ve İşten Ayrılma Niyeti Üzerine Etkisinde Aşırı İş Yükünün Aracılık Rolü, Ege Akademik Bakış, 13(1): 11-20.

Çöl, G. (2008). Algılanan Güçlendirmenin İşgören Performansı Üzerine Etkileri, Doğuş Üniversitesi Dergisi, 9(1): 35-46.

Demir, M. (2015). Konaklama İşletmelerinde Birey-Örgüt Uyumunun İş Performansı ve İşte Kalma Niyeti Üzerine Etkisi, Journal of Tourism Theory and Research, 1(2): 57-71.

Demirer, M. C. (2018). Kişi Örgüt Uyumunun İş Performansı Üzerine Etkisi: Mutluluğun Aracılık Rolü, İktisadi ve İdari Bilimler Dergisi, 33 (1): 283-301.

Güçlü, N. ve Şehitoğlu, E. T. (2006). Örgütsel Değişim Yönetimi, Kazım Karabekir Eğitim Fakültesi Dergisi, (13): 240-254.

Gül, H. (2007). İş Stresi, Örgütsel Sağlık ve Performans Arasındaki İlişkiler: Bir Alan Araştırması, Karaman İktisadi ve İdari Bilimler Fakültesi Dergisi, 3(2): 318-332.

Hasanhanoğlu, C. (2020). Covid-19'un İş Sağlığı ve Güvenliği Kapsamında İşletmeler Üzerine Etkileri, Uluslararası Ekonomi ve Siyaset Bilimleri Akademik Araştırmalar Dergisi, 4(10): 11-27.

Hoel, H. and Einarsen, S. (2003). Violence at Work in Hotels, Catering and Tourism, Geneva: International Labour Office. 
https://sozluk.gov.tr/ [Erişim Tarihi: 14.01.2021].

https://www.tga.gov.tr/t-c-kultur-ve-turizm-bakanligi-kontrollu-normallesme-surecigenelgeleri/ [Erişim tarihi: 08.04.2021].

İlhan, M. N., Gözükara, M. G. ve Aksu, E. (2017). Turizm Sektöründe İş Sağlığı ve Güvenliği ile İlgili Sorunlar ve Çözüm Önerileri, Gazi Üniversitesi Sağllk Bilimleri Dergisi, 2(2): 1-8.

İplik, F. N. (2004). Dört ve Beş Yıldızlı Otel işletmelerinde Çalışan Personelin Performans Değerlendirme Faaliyetleri: Çukurova Bölgesi Örneği, Anatolia: Turizm Araştırmaları Dergisi, 15(2): 195-205.

Kılıç, K. C. ve Yener, D. (2015). Birey-Örgüt ve Birey-İş Uyumunun Çalışanların İş Tutumlarına Etkisi: Adana İlinde Bankacılık Sektöründe Çalışanlar Üzerine Bir Araştırma, Ç.Ü. Sosyal Bilimler Enstitüsü Dergisi, 24(1): 161-174.

Kirkman, B. L. and Rosen, B. (1999). Beyond Self-Management: Antecedents and Consequences of Team Empowerment, Academy of Management Journal, 42(1): 58-74.

LePine, J. A., Colquitt, J. A. and Erez, A. (2000). Adaptability to Changing Task Contexts: Effects of General Cognitive Ability, Conscientiousness, and Openness to Experience, Personnel Psychology, 53(3): 563-593.

McCaughey, D., DelliFraine, J. L., McGhan, G. and Bruning, N. S. (2013). The Negative Effects of Workplace İnjury and İllness on Workplace Safety Climate Perceptions and Health Care Worker Outcomes, Safety Science, 51(1): 138-147.

Özkan, O. S., Omay, T. ve Akyüz, G. A. (2019). Psikolojik Sermaye, Bireysel Performans ve Birey-Örgüt Uyumu: Bir Literatür Taraması, Selçuk Üniversitesi Sosyal Bilimler Enstitüsü Dergisi, (41): 113-126.

Özkoç, A. G. (2014). Turizm İşletmelerinde Çalışan İlişkileri Yönetimi, (Editör) Tükeltürk, Ş. A., Perçin N. Ş. ve Güzel B.: Turizm İşletmelerinde Örgütsel Güven içinde (ss.39-58) Ankara: Detay Yayıncilik.

Pulakos, E. D., Arad, S., Donovan M. A. and Plamondon K. E. (2000). Adaptability in the Workplace: Development of Taxonomy of Adaptive Performance, Journal of Applied Psychology, 85(4): 612-624. doi: https://doi.org/10.1037/0021-9010.85.4.612

Sağlık Bakanlığı, (2020). Covid-19 Genel Bilgiler, Epidemiyoloji ve Tanı. [Online] https://covid19.saglik.gov.tr/Eklenti/38597/0/covid-

19rehberigenelbilgilerepidemiyolojivetanipdf.pdf [Erişim Tarihi: 10.01.2021].

Saltık, Z. (2016). Stresin İşgören Performansına ve İşten Ayrlma Niyetine Etkisi: Konaklama İşletmelerinde Bir Uygulama, Yayınlanmamış Yüksek Lisans Tezi, Nevşehir Hacı Bektaş Veli Üniversitesi, Nevşehir.

Sigler, T. H. and Pearson, C. M. (2000). Creating an Empowering Culture: Examining the Relationship Between Organizational Culture and Perceptions of Empowerment, Journal of Quality Management, 5: 27-52.

Sönmez, R. V. (2020). Covıd-19 Kaygısının İş Gören Performansı ve Motivasyonu Üzerine Etkisi: Hizmet Sektöründe Bir Araştırma. Avrasya Sosyal ve Ekonomi Araştırmaları Dergisi, 7(12), 155-175.

Tatlıcan, M. ve Çöğenli, M. Z. (2020). İş Sağlığı ve Güvenliği Performans Değerlendirme Uygulamalarının İş Tatmini Üzerine Etkisi: Endüstri İşletmesi Örneği, Uşak Üniversitesi Sosyal Bilimler Dergisi, 13(1): 181-194. 
Türk, M. ve Akbaba, M. (2017). Stratejik Liderlik Algılamalarının Çalışan Performansına Etkisi: Konaklama İşletmeleri Üzerine Bir Araştırma, Sosyal Bilimler Dergisi (SOBIDER), 4(16): 182-196.

Uysal, H. T. ve Yıldız, M. S. (2013). İşgören Performansı Açısından Çalışma Psikolojisinin Örgütsel Sinizme Etkisi, Uluslararası Sosyal Araştırmalar Dergisi, 7(29): 835-849.

Uysal, Ş. (2015). Performans Yönetimi Sisteminin Tanımı, Tarihçesi, Amaç ve Temel Unsurlarına Genel Bir Bakış, Electronic Journal of Vocational Colleges, 5(2): 32-39.

Üngüren, E. ve Koç, T. S. (2015). İş Sağlığı ve Güvenliği Uygulamaları Performans Değerlendirme Ölçeği: Geçerlik ve Güvenirlik Çalışması, Sosyal Güvenlik Dergisi, 5(2): 124-144.

Ünsalan, E. ve Şimşeker, B. (2013). Meslek Yüksekokulları İçin İnsan Kaynakları Yönetimi. (4. Baskı), Ankara: Detay Yayıncilı.

Yazıcıŏlu, İ. (2010). Örgütlerde İş Tatmini ve İşgören Performansı İlişkisi: Türkiye ve Kazakistan Karşılaştırması, Bilig Türk Dünyası Sosyal Bilimler Dergisi, (55): 243- 264.

Yiğitol, B. ve Büyükmumcu, S. (2021). Covid-19 Korkusu, Kişilik Özellikleri, İş Performansı ve İşten Ayrılma Niyeti Arasındaki Yordayıcı İlişkilerin İncelenmesi. OPUS Uluslararası Toplum Araştırmaları Dergisi, 17(Pandemi Özel Sayısı). 3414-3447. DOI: 10.26466/opus.890502. 